UDC 547.792”722.03/04.057

\author{
V. Zazharskyi ${ }^{a}$, M. Parchenko ${ }^{b}$, T. Fotina ${ }^{c}$, P. Davydenko ${ }^{a}$, O. Kulishenko ${ }^{a}$, \\ N. Zazharskaya ${ }^{a}$, I. Borovik $^{d}$
}

\title{
SYNTHESIS, STRUCTURE, PHYSICOCHEMICAL PROPERTIES AND ANTIBACTERIAL ACTIVITY OF 1,2,4-TRIAZOLES-3-THIOLS AND FURAN DERIVATIVES
}

\author{
${ }^{a}$ Dnipro State Agrarian and Economic University, Dnipro, Ukraine

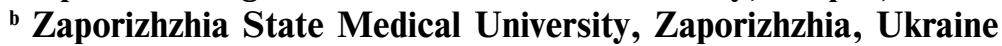 \\ c Sumy National Agrarian University, Sumy, Ukraine \\ d Dnipro Region State Laboratory of Veterinary Medicine, Dnipro, Ukraine
}

\begin{abstract}
New compounds, 5- $\mathrm{R}_{2}$-2- (furan-2-yl-,5-bromofuran-2-yl) thiazolo [3,2-b][1,2,4] triazole$4(5 \mathrm{H})$-ones, have been synthesized with a high yield for the first time. Molecules of these compounds contain the residuals of 1,2,4-triazole-3-thiols and furan. The reaction of their reduction by an excess of sodium borohydride was investigated. The structure of the synthesized compounds was confirmed by NMR ${ }^{1} \mathrm{H}$ spectroscopy, X-ray microanalysis and chromatography. The reduction of 5- $\mathrm{R}_{2}-2$-(furan-2-yl-,5-bromofuran-2-yl) thiazolo [3,2-b] $[1,2,4]$ triazole-4 $(5 \mathrm{H})$-ones in a methanol medium in the presence of a triple quantity of sodium borohydride occurs with the formation of corresponding $3-\mathrm{R}_{2}-2-((3-$ (furan-2-yl, 5-bromofuran-2-yl)-1,2,4-triazol-5-yl) thio)-prop-2-en-1-oles. The antibacterial activity of the synthesized compounds towards the cryogenic strains of Enterococus faecalis, Proteus mirabilis, Proteus vulgaris, Serratia marcense, Salmonella adobraco, Salmonella typhimurium, Staphylococcus epidermidis, Bacillus subtilis, Listeria ivanovi, Listeria innocua, Listeria monocytogenes, Campylobacter jejuni, Rhodococcus equi and Candida albicans was investigated. According to the obtained data, the investigated compounds can compete with kanamycin, a natural broad-spectrum antibiotic from the second generation of aminoglycosides, the action spectrum of which includes gram-positive and gram-negative microorganisms. The compounds involved may be recommended for further investigations concerning multi-resistant strains of microorganisms.
\end{abstract}

Keywords: cyclization, 1,2,4-triazole, reduction, physicochemical properties, antibacterial activity.

DOI: $10.32434 / 0321-4095-2019-127-6-74-82$

\section{Introduction}

The chemistry of heterocyclic compounds is known to be of great interest for the development of organic chemistry in general. A special attention is paid to derivatives of 1,2,4-triazoles [1-3]. Generally, 1,2,4-triazoles are low-toxic compounds that have a wide range of valuable chemical and biological properties. Some of them are active pharmaceutical ingredients of many medicines [1,3], substances of plant growth regulators and fertilizers [4], and biologically active compounds that are at the preclinical testing stage [5]. Kumar et al. [6] reported antibacterial and antifungal efficiency of synthesized 3-(o-nitrophenyl)-5-arylthiazolo [2,3-c] pyridin-2- one (2-octanyl)-6-arylthiazolo [3,2-b] [1,2,4] triazoles and their isomers. Triazoles can also be used to preserve food [7-9].

The approach to combine 1,2,4-triazole with various fragments of other organic compounds seems to be promising $[1,3,5]$. This fact gives undeniable scientific evidence of the practical feasibility of the existence of molecules formed via such transformations [10].

Our attention was drawn to the possibility of combining structural fragments of 1,2,4-triazole-3thiol and furan to form one molecule, since each of these systems separately demonstrates a wide range of biological properties or is a structural fragment of

(C) V. Zazharskyi, M. Parchenko, T. Fotina, P. Davydenko, O. Kulishenko, N. Zazharskaya, I. Borovik, 2019

V. Zazharskyi, M. Parchenko, T. Fotina, P. Davydenko, O. Kulishenko, N. Zazharskaya, I. Borovik 
active pharmaceutical ingredients of some drugs $[1,6,10]$.

Thus, the purpose of our work was to synthesize compounds in which molecules contain the residuals 1,2,4-triazole-3-thiols and furans, namely a number of new 5- $\mathrm{R}_{2}$-2-(furan-2-yl-, 5-bromofuran-2-yl) thiazolo $[3,2-b][1,2,4]$ triazole-4 $(5 \mathrm{H})$-ones. In addition, the aim of the work was to investigate the reaction of their reduction by an excess of sodium borohydride, determine their physicochemical properties, and estimate antibacterial activity of the new compounds.

\section{Material and methods}

5-(Furan-2-yl)-4H-1,2,4-triazole-3-thiol (Fig. 1, compound 1) and 5-(5-bromofuran-2-yl)4H-1,2,4-triazole-3-thiol (Fig. 1, compound 2) were used as initial reagents. A mixture containing $0.01 \mathrm{~mol}$ of 2-(5- (furan-2-yl)-4H-1,2,4-triazole-3-ylthio) acetate, 2-(5-(5-bromofuran-2-yl)-4H-1,2,4-triazol3 -ylthio) acetate (Fig. 1, compounds 3 and 4), $0.01 \mathrm{~mol}$ of the corresponding carbonyl compound (benzaldehyde, 4-bromobenzaldehyde, 2-ethoxybenzaldehyde, or 3-bromo-4-hydroxy-5-methoxybenzaldehyde), $5 \mathrm{~cm}^{3}$ of acetic anhydride and $20 \mathrm{~cm}^{3}$ of acetic acid were boiled for 1 hour. The formed precipitate was filtered out. The compounds of yellow (5-7) and light yellow (8) colors, insoluble in water, soluble in dimethylformamide were obtained. For the analysis, the compounds were purified by crystallization from acetic acid.

The scheme of the synthesis is given in the section Results and discussion (Fig. 1). Subsequent transformations lead to the compound 4, for which the cyclization reaction with aromatic aldehyde was firstly investigated under similar conditions by the method described elsewhere [10]. Thus, a number of new derivatives (Table 1, No. 9-15) were prepared. Compounds (5-8) (Table 1) were resynthesized by our research team. In this paper, we will discuss the formation and properties of compounds $(9-15)$ (Fig. 1).

Synthesis was performed by the addition of equivalent amounts of aromatic aldehydes to acetic acid in the presence of acetic anhydride at boiling during two hours. The synthesized compounds were obtained with a high yield (Table 1, No. 5-15).

The reduction of 5- $\mathrm{R}_{2}-2$-(furan-2-yl-, 5bromofuran-2-yl) thiazolo $[3,2-b][1,2,4]$ triazole-4 (5H)-one (Table 1,5-15) was carried out in methanol medium in the presence of a triple quantity of sodium borohydride. The mixture was left for 24 hours. Then, the solvent was evaporated, chloroform was added to the dry residue, the mixture was filtered, and chloroform was evaporated. Thus, we got a number of new compounds for the first time (Table 2 , $16-22)$.

We also investigated the reduction of 5-benzylidene-2-(3-fluorophenyl) thiazolo [3,2-c]-1,2,4triazole-6- $(5 H)$-one in the presence of an excess of sodium borohydride. This process occurs with the closure of the ring and the formation of 3-aryl-2((3-(3-fluorophenyl)-1,2,4-triazol-5-yl) thio) prop2-en-1-ol [10]. That work revealed the structures of the synthesized compounds (Table 1, 9-15) using complex of physicochemical methods of analysis, and the individuality of the reaction products was evidenced by chromatography technique. In some cases, X-ray diffraction analysis was used for the final confirmation of the structure of the molecule.

Melting points were determined by a Kofler apparatus. The NMR ${ }^{1} \mathrm{H}$ and ${ }^{13} \mathrm{C}$ spectra were recorded in DMSO-d6 at $400 \mathrm{MHz}$ using a Varian MR-400 spectrometer and analyzed with ADVASPTM Analyzer software (Umatek International Inc.). The chemical shifts are reported in ppm ( $\delta$ scale) down field with residual protons of the solvent (DMSO-d6, $\delta=2.49 \mathrm{ppm})$ as internal standard. The EI mass spectra were obtained using Varian 1200L facility with electron energy of $70 \mathrm{eV}$.

Antibacterial activity of the investigated compounds was determined by the method of agar disc diffusion. A suspension was prepared from a daily culture of reference cryogenic strains of 17 microorganisms according to the turbidity standard of a bacterial suspension of 0.5 units (Mac Farland $1.5 \cdot 10^{8} \mathrm{CFU}$ ) using Densimeter II. The resulting suspension was subcultured on Muller-Hinton agar (Himedia), followed by the cultivation in a thermostat for 24 and 48 hours at $37^{\circ} \mathrm{C}$. Discs soaked in appropriate extracts were placed on top of the subcultures. Discs with $30.0 \mu \mathrm{g}$ of kanamycin (0-3amino-3-deoxy-alpha-D-glucopyranosyl-(1 "6)-0-[6amino-6-deoxy-alpha-D-glucopyrinazyl-[1" 4)]-2deoxy-D-streptamine) served as a positive control [11]. Discs with $15.0 \mathrm{mg}$ of amphotericinin (1R, 3S, 5R, 6R, 9R, 11R, 15S, 16R, 17R, 18S, 19E, 21E, 23E, 25E, 27E, 29E, 31E, 33R, 35S, 36R, 37S)-33[(3-amino-3,6-dideoxy- $\beta$-D-mannopyranosyl)oxy]$1,3,5,6,9,11,17,37$-octahydroxy-15, 16, 18trimethyl-13-oxo-14, 39-dioxabicyclo [33.3.1] nonatriaconta-19, 21, 23, 25, 27, 29, 31-heptaene36-carboxylic acid) were also used as a second control towards Candida albicans.

After 24 hours of incubation, the diameter of the culture growth inhibition zone was measured using a template for measuring the size of microorganism growth inhibition zones (Antibiotic Zone Scale-C, model PW297, India) and TpsDig2 
software.

\section{Results and discussion}

It is known that bicyclic derivatives of $1,2,4-$ triazole exhibit various types of pharmacological action $[1,4]$. Chemical transformation of the compounds in our case can lead to the emergence of new unique molecules with interesting properties. The synthesis of some derivatives of 1,2,4-triazole with fragments of the nucleus of furan has been already described [10]. Therefore, using the above methodology, we have resynthesized the initial compounds, which were subsequently used as intermediates to obtain other classes of derivatives of 1,2,4-triazole.

The pathway of the cyclization reaction and the formation of bicyclic systems of 1,2,4-triazoles is shown in Fig. 1. The structures of the synthesized compounds are illustrated in Fig. 2.

Physical properties and chemical composition of synthesized 5- $\mathrm{R}_{2}$-2-(furan-2-yl-, 5-bromofuran2 -yl) thiazolo $[3,2-b][1,2,4]$ triazole-4 $(5 H)$-ones are summarized in Tables 1 and 2.

5- $\mathrm{R}_{2}$-2-(Furan-2-yl-, 5-bromofuran-2-yl) thiazolo $[3,2-b][1,2,4]$ triazole-4 $(5 H)$-ones (Table 1,9-15) are individual crystalline compounds with light yellow (11), yellow (13), orange $(10,12,14)$, or brown $(9,15)$ colors, insoluble in water and soluble in dimethylformamide. For the analysis, these compounds have been recrystallized from acetic acid.

According to the data of $\mathrm{NMR}{ }^{1} \mathrm{H}$ spectra of the synthesized compounds (Table 1, No. 9-15), we can draw some conclusions. First, there are characteristic signals of the furan cycle in the region typical of aromatic compounds in the form of extended singlet or doublets (at 6.83-6.85 and 7.25$7.26 \mathrm{ppm}$ ). In turn, the signal of an ethylene spacer that combines the thiazolo $[3,2-b][1,2,4]$ triazole- 6 $(5 \mathrm{H})$-one fragment with the phenyl radical is recorded<smiles>[R]C(=O)C(C)CC(=O)OC(C)C(=O)OCC(=O)O</smiles>
1,2

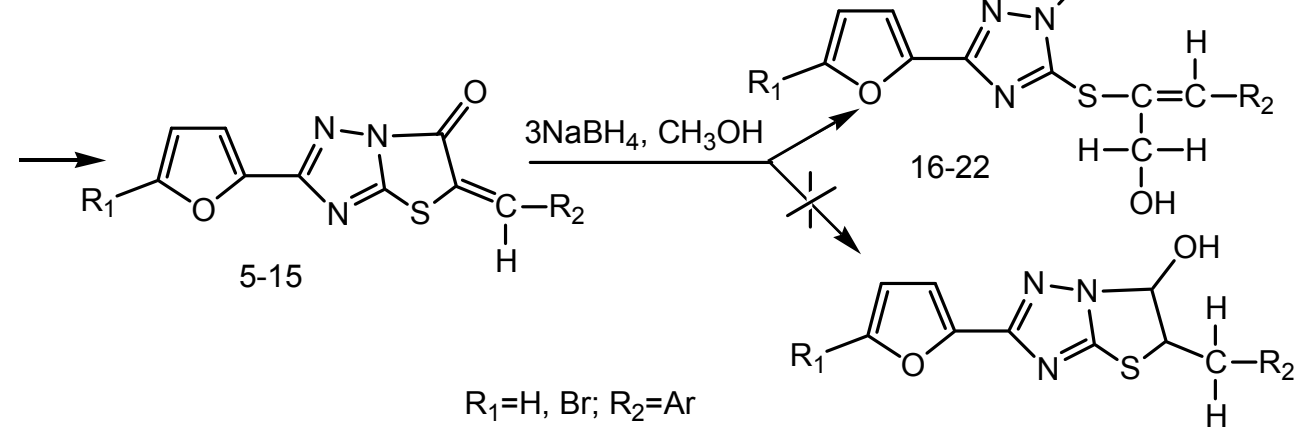

Fig. 1. The scheme of the synthesis and reduction of 5- $\mathrm{R}_{2}-2-($ furan-2-yl-, 5-bromofuran-2-yl) thiazolo $[3,2-b][1,2,4]$ triazole-4 $(5 H)$-ones<smiles>[R]C=c1sc2nc(-c3ccc([R])o3)nn2c1=O</smiles>

a<smiles></smiles>

b

Fig. 2 The structure of 5- $\mathrm{R}_{2}$-2-(furan-2-yl-, 5-bromofuran-2-yl) thiazolo [3,2-b] [1,2,4] triazole-4 (5H)-ones (a) where $\mathrm{R}_{2}$ is

3-fluorophenyl (compound 9); 4-fluorophenyl (compound 10); 4-hydroxyphenyl (compound 11); 3,4-dimethoxyphenyl (compound 12); 3,5-dimethoxyphenyl (compound 13); 4-nitrophenyl (compound 14); 2-carboxyphenyl (compound 15); and 3- $\mathrm{R}_{2}$-2-(furan-2-yl-, 5-bromofuran-2-yl) -1,2,4-triazol-5-yl) thio) prop-2-en-1-oles (b) where $\mathrm{R}_{2}$ is phenyl (compound 16); 4-bromophenyl (compound 17); 2-etoxyphenyl (compound 18); 3-bromo-4-oxy-5-methoxy (compound 19); 4-hydroxyphenyl (compound 20); 3,4-dimethoxyphenyl (compound 21); 3,5-dimethoxyphenyl (compound 22) 
at $8.26-8.35 \mathrm{ppm}$ in the form of a singlet. It is noteworthy that these signals are shifted in a weak field due to a strong acceptor in the form of the phenyl radical and a decrease of the electronic density on a double bond. Aromatic protons resonated in the form of triplets (two doublets in the region of 7.43-8.33 ppm [12]) (Figs. 3, 4).

The data of NMR spectra are given below:

5-(3-fluorophenyl)-2-(furan-2-yl-, 5-bromofuran-2-yl) thiazolo $[3,2-b][1,2,4]$ triazole-4 $(5 H)$ one (compound 9): NMR ${ }^{1} \mathrm{H}$ (400 MHz, DMSO-d6) $\delta$ ppm $6.83(\mathrm{~d}, J=3.36 \mathrm{~Hz}, 1 \mathrm{H}) 7.25(\mathrm{~d}, J=3.36 \mathrm{~Hz}$, $1 \mathrm{H})$ 7.37-7.44 (m, $1 \mathrm{H})$ 7.53-7.65 (m, $3 \mathrm{H}) 8.22$ (s, $1 \mathrm{H})$;

5-(4-fluorophenyl)-2-(furan-2-yl-, 5 bromofuran-2-yl) thiazolo $[3,2-b][1,2,4]$ triazole-4 (5H)-one (compound 10): NMR ${ }^{1} \mathrm{H}(400 \mathrm{MHz}$, DMSO- $\left.d_{6}\right) \delta$ ppm 6.85 (br. s., $\left.1 \mathrm{H}\right) 7.26$ (br. s., 1 H) $7.43(\mathrm{t}, J=8.39 \mathrm{~Hz}, 2 \mathrm{H}) 7.82(\mathrm{t}, J=8.40 \mathrm{~Hz}, 2$ H) $8.26(\mathrm{~s}, 1 \mathrm{H})$;

5-(4-hydroxyphenyl)-2-(furan-2-yl-, 5bromofuran-2-yl) thiazolo $[3,2-b][1,2,4]$ triazole-4

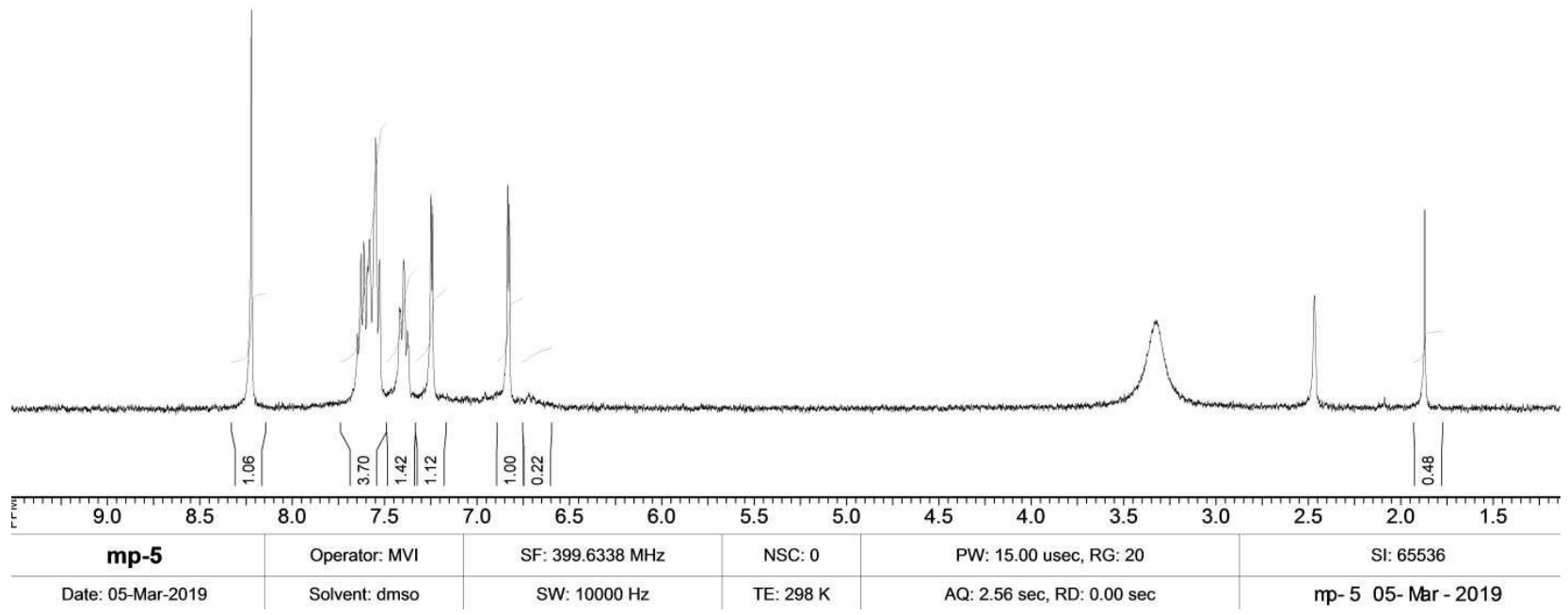

Fig. 3. NMR ${ }^{1} \mathrm{H}$ spectrum of 5-(3-fluorophenyl)-2-(furan-2-yl-, 5-bromofuran-2-yl) thiazolo [3,2-b] [1,2,4] triazole-4 (5H)-one (compound 9)

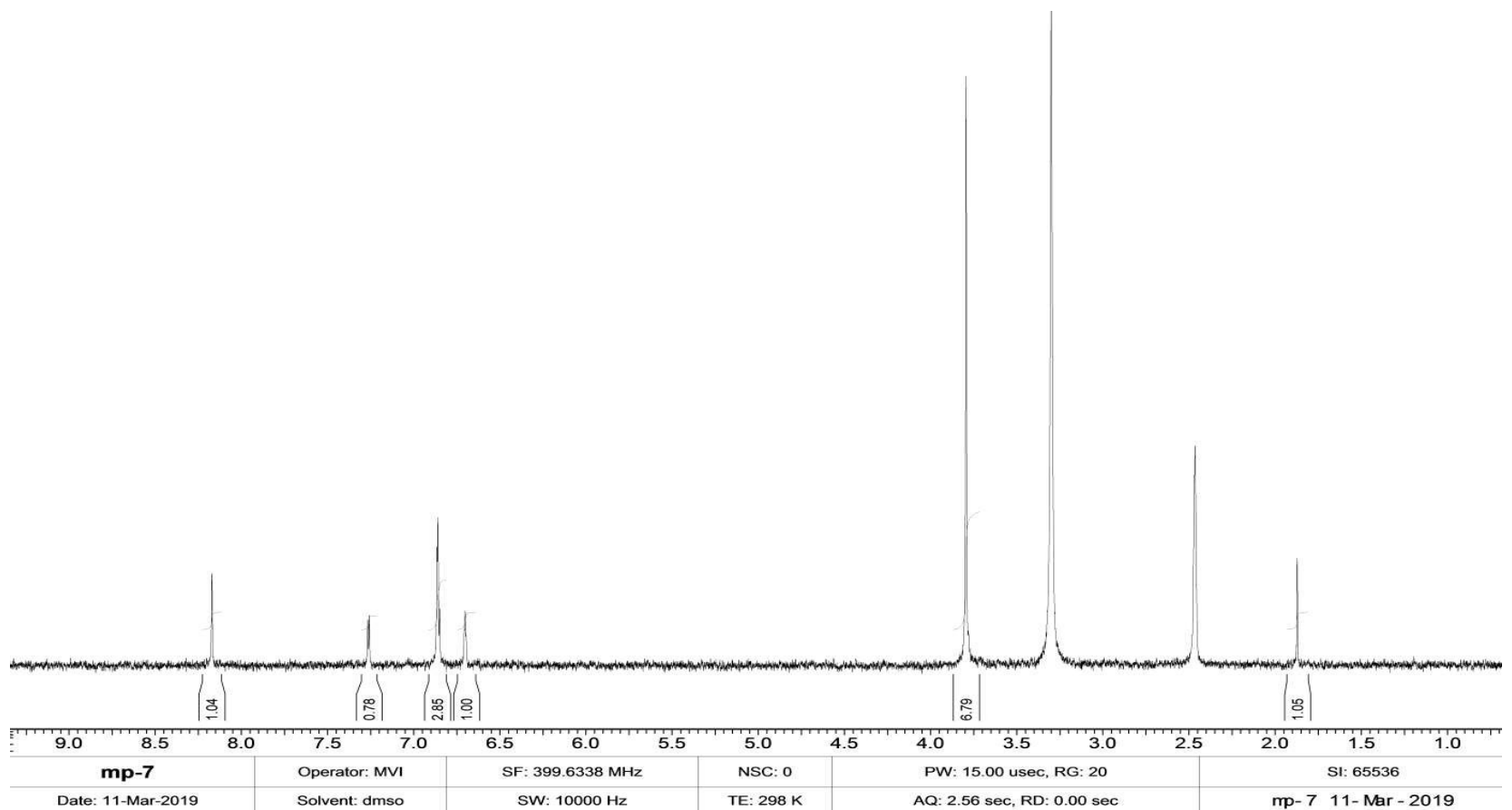

Fig. 4. NMR ${ }^{1} \mathrm{H}$ spectrum of 5-(2,5-dimethoxyphenyl)-2-(furan-2-yl-, 5-bromofuran-2-yl) thiazolo [3,2-b] [1,2,4] triazole-4 $(5 H)$-one (compound 13)

Synthesis, structure, physicochemical properties and antibacterial activity of 1,2,4-triazoles-3-thiols and furan derivatives 
Table 1

Some properties of 5- $\mathrm{R}_{2}-2$-(furan-2-yl-, 5-bromofuran-2-yl) thiazolo [3,2-b] [1,2,4] triazole-4 $(5 H)$-ones and 3- $\mathrm{R}_{2}$ 2-(furan-2-yl-, 5-bromofuran-2-yl)-1,2,4-triazol-5-yl) thio) prop-2-en-1-oles

\begin{tabular}{c|c|l|c|l|c}
\hline No. & $\mathrm{R}_{1}$ & \multicolumn{1}{|c|}{$\mathrm{R}_{2}$} & Melting point, ${ }^{0} \mathrm{C}$ & \multicolumn{1}{|c}{ Formula } & Yield, \% \\
\hline 5 & $\mathrm{H}$ & phenyl & $207-209$ & $\mathrm{C}_{15} \mathrm{H}_{9} \mathrm{~N}_{3} \mathrm{O}_{2} \mathrm{~S}^{*}$ & - \\
\hline 6 & $\mathrm{H}$ & 4-bromophenyl & $253-255$ & $\mathrm{C}_{15} \mathrm{H}_{8} \mathrm{BrN}_{3} \mathrm{O}_{2} \mathrm{~S}^{*}$ & - \\
\hline 7 & $\mathrm{H}$ & 2-etoxyphenyl & $195-197$ & $\mathrm{C}_{17} \mathrm{H}_{13} \mathrm{~N}_{3} \mathrm{O}_{3} \mathrm{~S}^{*}$ & - \\
\hline 8 & $\mathrm{H}$ & 3-bromo-4-oxy-5-methoxy & $214-216$ & $\mathrm{C}_{16} \mathrm{H}_{10} \mathrm{BrN}_{3} \mathrm{O}_{4} \mathrm{~S}^{*}$ & - \\
\hline 9 & $\mathrm{Br}$ & 3-fluorophenyl & $210-212$ & $\mathrm{C}_{15} \mathrm{H}_{7} \mathrm{BrFN}_{3} \mathrm{O}_{2} \mathrm{~S}$ & 90 \\
\hline 10 & $\mathrm{Br}$ & 4-fluorophenyl & $245-247$ & $\mathrm{C}_{15} \mathrm{H}_{7} \mathrm{BrFN}_{3} \mathrm{O}_{2} \mathrm{~S}$ & 77 \\
\hline 11 & $\mathrm{Br}$ & 4-hydroxyphenyl & $205-207$ & $\mathrm{C}_{15} \mathrm{H}_{8} \mathrm{BrN}_{3} \mathrm{O}_{3} \mathrm{~S}$ & 92 \\
\hline 12 & $\mathrm{Br}$ & 3,4-dimethoxyphenyl & $295-297$ & $\mathrm{C}_{17} \mathrm{H}_{12} \mathrm{BrN}_{3} \mathrm{O}_{4} \mathrm{~S}$ & 81 \\
\hline 13 & $\mathrm{Br}$ & 3,5-dimethoxyphenyl & $252-254$ & $\mathrm{C}_{17} \mathrm{H}_{12} \mathrm{BrN}_{3} \mathrm{O}_{4} \mathrm{~S}$ & 76 \\
\hline 14 & $\mathrm{Br}$ & 4-nitrophenyl & $288-290$ & $\mathrm{C}_{15} \mathrm{H}_{7} \mathrm{BrN}_{4} \mathrm{O}_{4} \mathrm{~S}$ & 82 \\
\hline 15 & $\mathrm{Br}$ & 2-carboxyphenyl & $250-252$ & $\mathrm{C}_{16} \mathrm{H}_{8} \mathrm{BrN}_{3} \mathrm{O}_{4} \mathrm{~S}$ & 68 \\
\hline 16 & $\mathrm{H}$ & phenyl & $207-209$ & $\mathrm{C}_{15} \mathrm{H}_{9} \mathrm{~N}_{3} \mathrm{O}_{2} \mathrm{~S}$ & 57 \\
\hline 17 & $\mathrm{H}$ & 4-bromophenyl & $198-200$ & $\mathrm{C}_{15} \mathrm{H}_{8} \mathrm{BrN}_{3} \mathrm{O}_{2} \mathrm{~S}$ & 63 \\
\hline 18 & $\mathrm{H}$ & 2-etoxyphenyl & $117-119$ & $\mathrm{C}_{17} \mathrm{H}_{13} \mathrm{~N}_{3} \mathrm{O}_{3} \mathrm{~S}$ & 60 \\
\hline 19 & $\mathrm{H}$ & 3-bromo-4-oxy-5-methoxy & $125-127$ & $\mathrm{C}_{16} \mathrm{H}_{10} \mathrm{BrN}_{3} \mathrm{O}_{4} \mathrm{~S}$ & 54 \\
\hline 20 & $\mathrm{Br}$ & 4-hydroxyphenyl & $230-232$ & $\mathrm{C}_{15} \mathrm{H}_{12} \mathrm{BrN}_{3} \mathrm{O}_{3} \mathrm{~S}$ & 73 \\
\hline 21 & $\mathrm{Br}$ & 3,4-dimethoxyphenyl & $98-100$ & $\mathrm{C}_{17} \mathrm{H}_{16} \mathrm{BrN}_{3} \mathrm{O}_{4} \mathrm{~S}$ & 63 \\
\hline 22 & $\mathrm{Br}$ & 3,5-dimethoxyphenyl & $95-97$ & $\mathrm{C}_{17} \mathrm{H}_{16} \mathrm{BrN}_{3} \mathrm{O}_{4} \mathrm{~S}$ & 61 \\
\hline
\end{tabular}

Note: ${ }^{*-}$ Melting points are coincided with the literature data [10].

Table 2 (5H)-one (compound 12): NMR ${ }^{1} \mathrm{H}(400 \mathrm{MHz}$,

Elemental composition of 5- $\mathbf{R}_{2}-2$-(furan-2-yl-, 5 -

bromofuran-2-yl) thiazolo $[3,2-b][1,2,4]$ triazole-4

(5H)-ones and 3- $\mathrm{R}_{2}-2$-(furan-2-yl-, 5-bromofuran-2-yl)1,2,4-triazol-5-yl) thio) prop-2-en-1-oles

\begin{tabular}{c|c|c|c|c|c|c|c|c}
\hline \multirow{2}{*}{ No. } & \multicolumn{4}{|c|}{ Found, \% } & \multicolumn{4}{c}{ Calculated, \% } \\
\cline { 2 - 9 } & $\mathrm{C}$ & $\mathrm{H}$ & $\mathrm{N}$ & $\mathrm{S}$ & $\mathrm{C}$ & $\mathrm{H}$ & $\mathrm{N}$ & $\mathrm{S}$ \\
\hline 9 & 45.87 & 1.77 & 10.63 & 8.15 & 45.94 & 1.80 & 10.71 & 8.18 \\
\hline 10 & 45.87 & 1.75 & 10.66 & 8.12 & 45.94 & 1.80 & 10.71 & 8.18 \\
\hline 11 & 45.88 & 2.02 & 10.84 & 8.15 & 46.17 & 2.07 & 10.77 & 8.22 \\
\hline 12 & 46.77 & 2.74 & 9.65 & 7.33 & 47.02 & 2.79 & 9.68 & 7.38 \\
\hline 13 & 46.85 & 2.69 & 9.54 & 7.35 & 47.02 & 2.79 & 9.68 & 7.38 \\
\hline 14 & 43.08 & 1.69 & 13.27 & 7.59 & 42.98 & 1.68 & 13.36 & 7.65 \\
\hline 15 & 45.84 & 1.87 & 10.02 & 7.64 & 45.95 & 1.93 & 10.05 & 7.67 \\
\hline 16 & 60.11 & 4.33 & 14.08 & 10.66 & 60.18 & 4.38 & 14.04 & 10.71 \\
\hline 17 & 47.57 & 3.17 & 11.13 & 8.47 & 47.63 & 3.20 & 11.11 & 8.48 \\
\hline 18 & 59.41 & 4.87 & 12.22 & 9.28 & 59.46 & 4.99 & 12.24 & 9.34 \\
\hline 19 & 45.07 & 3.27 & 9.81 & 7.53 & 45.29 & 3.33 & 9.90 & 7.56 \\
\hline 20 & 45.62 & 3.00 & 10.55 & 8.11 & 45.70 & 3.07 & 10.66 & 8.13 \\
\hline 21 & 46.44 & 3.59 & 9.52 & 7.28 & 46.59 & 3.68 & 9.59 & 7.32 \\
\hline 22 & 46.54 & 3.62 & 9.52 & 7.31 & 46.59 & 3.68 & 9.59 & 7.32 \\
\hline
\end{tabular}

(5H)-one (compound 11): NMR ${ }^{1} \mathrm{H}(400 \mathrm{MHz}$, DMSO- $\left.d_{6}\right) \delta$ ppm $6.84(\mathrm{~d}, J=3.36 \mathrm{~Hz}, 1 \mathrm{H}) 7.25(\mathrm{~d}$, $J=3.05 \mathrm{~Hz}, 1 \mathrm{H}) 7.35(\mathrm{~d}, J=7.93 \mathrm{~Hz}, 1 \mathrm{H}) 7.78(\mathrm{~d}$, $J=8.24 \mathrm{~Hz}, 1 \mathrm{H}) 8.12(\mathrm{~s}, 1 \mathrm{H}) 8.24(\mathrm{~s}, 1 \mathrm{H})$;

5-(3,4-dimethoxyphenyl)-2-(furan-2-yl-, 5bromofuran-2-yl) thiazolo $[3,2-b][1,2,4]$ triazole-4 DMSO- $\left.d_{6}\right) \delta \mathrm{ppm} 3.78(\mathrm{~s}, 6 \mathrm{H}) 6.69(\mathrm{~s}, 1 \mathrm{H}) 6.83-$ $6.86(\mathrm{~m}, 3 \mathrm{H}) 7.25(\mathrm{~d}, J=3.36 \mathrm{~Hz}, 1 \mathrm{H}) 8.17(\mathrm{~s}, 1$ $\mathrm{H})$;

5-(3,5-dimethoxyphenyl)-2-(furan-2-yl-, 5bromofuran-2-yl) thiazolo $[3,2-b][1,2,4]$ triazole-4 (5H)-one (compound 13): NMR ${ }^{1} \mathrm{H}(400 \mathrm{MHz}$, DMSO- $\left.d_{6}\right) \delta \mathrm{ppm} 3.79(\mathrm{~s}, 6 \mathrm{H}) 6.70(\mathrm{~s}, 1 \mathrm{H}) 6.84-$ $6.87(\mathrm{~m}, 3 \mathrm{H}) 7.26(\mathrm{~d}, J=3.36 \mathrm{~Hz}, 1 \mathrm{H}) 8.17(\mathrm{~s}, 1$ $\mathrm{H})$;

5-(4-nitrophenyl)-2-(furan-2-yl-, 5bromofuran-2-yl) thiazolo $[3,2-b][1,2,4]$ triazole-4 (5H)-one (compound 14): NMR ${ }^{1} \mathrm{H}(400 \mathrm{MHz}$, DMSO- $\left.d_{6}\right) \delta$ ppm $6.83(\mathrm{~d}, J=3.36 \mathrm{~Hz}, 1 \mathrm{H}) 7.25(\mathrm{~d}$, $J=3.36 \mathrm{~Hz}, 1 \mathrm{H}) 7.95(\mathrm{~d}, J=8.55 \mathrm{~Hz}, 2 \mathrm{H}) 8.33(\mathrm{~d}$, $J=3.05 \mathrm{~Hz}, 2 \mathrm{H}) 8.35(\mathrm{~s}, 1 \mathrm{H})$;

5-(2-carboxyphenyl)-2-(furan-2-yl-, 5bromofuran-2-yl) thiazolo $[3,2-b][1,2,4]$ triazole-4 (5H)-one (compound 15): NMR ${ }^{1} \mathrm{H}(400 \mathrm{MHz}$, DMSO- $\left.d_{6}\right) \delta \mathrm{ppm} 6.84(\mathrm{~d}, J=3.36 \mathrm{~Hz}, 1 \mathrm{H}) 7.24(\mathrm{~d}$, $J=3.36 \mathrm{~Hz}, 1 \mathrm{H}) 7.83(\mathrm{~d}, J=8.55 \mathrm{~Hz}, 2 \mathrm{H}) 8.27(\mathrm{~d}$, $J=3.05 \mathrm{~Hz}, 2 \mathrm{H}) 10.89(\mathrm{~s}, 1 \mathrm{H}) 8.33(\mathrm{~s}, 1 \mathrm{H})$.

3- $\mathrm{R}_{2}$-2-(furan-2-yl-, 5-bromofuran-2-yl)-1,2,4triazol-5-yl) thio) prop-2-en-1-oles are individual crystalline compounds with yellow (Table $3,16,18$, and 20-22,), orange (Table 3, 17 and 19) colors, insoluble in water and soluble in dimethylformamide. For the analysis, the above compounds have been recrystallized from methanol. 
According to theoretical assumptions, the reaction of reduction can occur in different ways, that is, path $\mathrm{a}$ or $\mathrm{b}$ in Fig. 1, forming individual compounds or a mixture thereof. In connection with the fact that the reduction was carried out under the same conditions, we can assume that it passes precisely with the formation of 3- $\mathrm{R}_{2}-2-((3-$ (furan2-yl, 5-bromofuran-2-yl)-1,2,4-triazol-5-yl) thio)prop-2-en-1-ol (Fig. 1), via the path a.

NMR ${ }^{1} \mathrm{H}$ spectra of compounds (16-22) (Table 3 ) are characterized by a singlet signal of an ethylene spacer in a weak field. It is noteworthy that the donor effect of methoxy groups in the 3.5-position and shifting the signal in a strong field at $6.71 \mathrm{ppm}$ was observed in contrast to compound 21 , in which the signal is recorded at $8.29 \mathrm{ppm}$. This evidences the reverse effect and manifestation of acceptor properties of phenyl. The aromatic nucleus of phenyl classically resonates in the form of multiplets in the area of $6.28-6.71 \mathrm{ppm}$. Characteristic signals of the furan cycle are observed in the region typical of aromatic compounds in the form of multiplets or doublets at
6.35-6.82 ppm. Particular attention should be paid to the group $-\mathrm{CH}_{2}-\mathrm{OH}$ in the ethylene spacer, which resonates as a complex multiplet for the methylene group at 3.62-3.77 ppm (which in fact consists of two complex triplets) and a triplet for the hydroxyl group at $4.27-4.32 \mathrm{ppm}$ (Fig. 5).

The data of NMR spectra are given below:

3-Phenyl-2-(furan-2-yl-, 5-bromofuran-2-yl)1,2,4-triazol-5-yl) thio) prop-2-en-1-ole (compound 16): NMR ${ }^{1} \mathrm{H}(400 \mathrm{MHz}, \mathrm{DMSO}-\mathrm{d} 6) \delta \mathrm{ppm} 3.64-$ $3.78(\mathrm{~m}, 2 \mathrm{H}) 4.28-4.34(\mathrm{~m}, 1 \mathrm{H}) 6.57(\mathrm{~d}, \mathrm{~J}=3.36$ $\mathrm{Hz}, 1 \mathrm{H}) 6.56-6.69(\mathrm{~m}, 3 \mathrm{H}) 6.78-6.82(\mathrm{~m}, 1 \mathrm{H})$ $8.25(\mathrm{~s}, 1 \mathrm{H})$

3-(4-bromophenyl)-2-(furan-2-yl-, 5-bromofuran-2-yl)-1,2,4-triazol-5-yl) thio) prop-2-en-1-ole (compound 17): NMR ${ }^{1} \mathrm{H}$ (400 MHz, DMSO-d6) $\delta$ ppm 3.64-3.78 (m, 2 H) 4.28-4.34 (m, $1 \mathrm{H}) 6.57$ $(\mathrm{d}, \mathrm{J}=3.36 \mathrm{~Hz}, 1 \mathrm{H}) 6.65-6.71(\mathrm{~m}, 3 \mathrm{H}) 6.78-6.82$ $(\mathrm{m}, 1 \mathrm{H}) 8.17(\mathrm{~s}, 1 \mathrm{H})$;

3-(2-etoxyphenyl)-2-(furan-2-yl-, 5-bromofuran-2-yl)-1,2,4-triazol-5-yl) thio) prop-2-en-1-ole (compound 18): NMR ${ }^{1} \mathrm{H}$ (400 MHz, DMSO-d6)

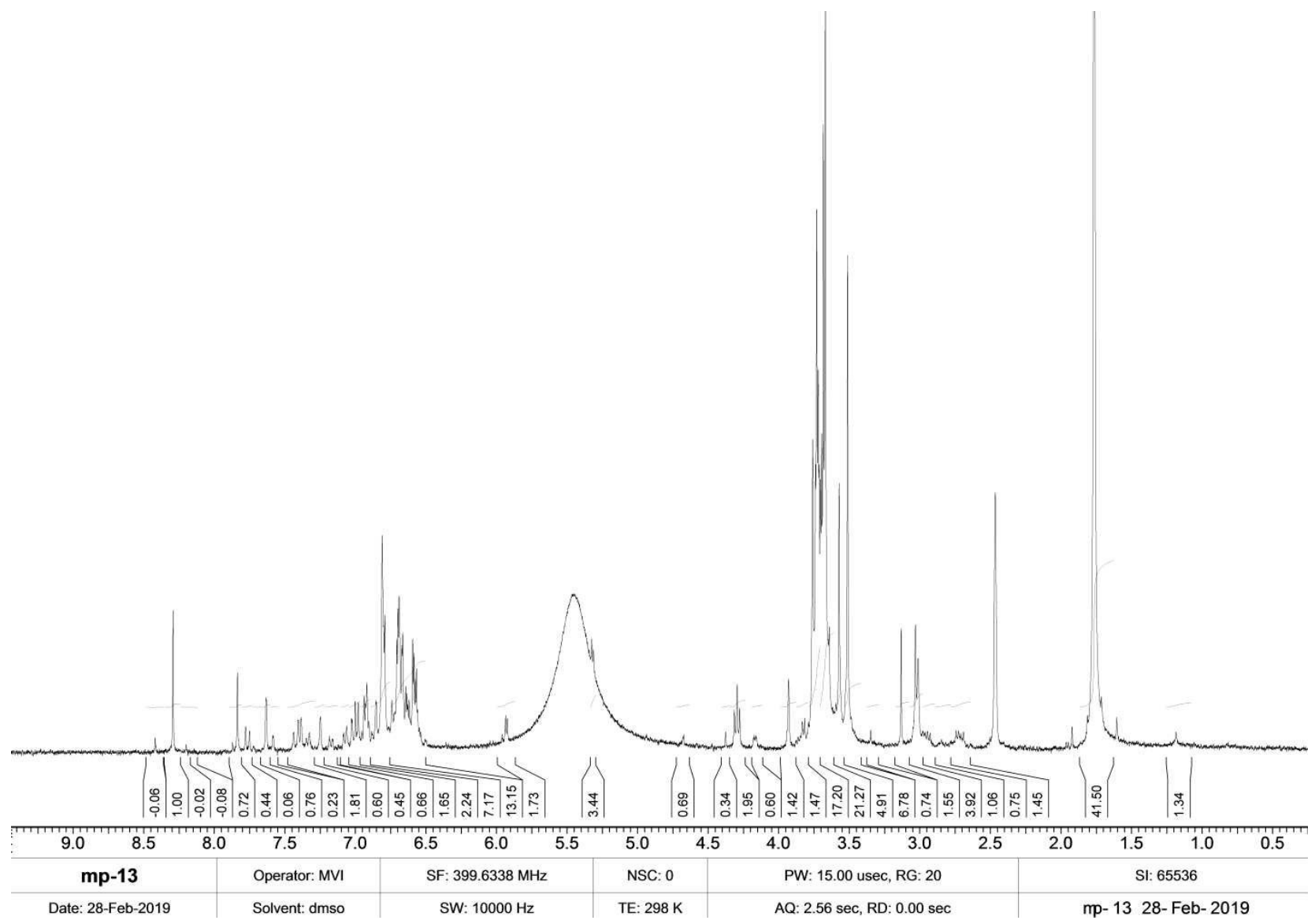

Fig. 5. NMR ${ }^{1} \mathrm{H}$ spectrum of 3-(3,4-dimethoxyphenyl)-2-(furan-2-yl-,

5-bromofuran-2-yl)-1,2,4-triazol-5-yl) thio) prop-2-en-1-ole (compound 21)

Synthesis, structure, physicochemical properties and antibacterial activity of 1,2,4-triazoles-3-thiols and furan derivatives 
$\delta$ ppm $1.23(\mathrm{~s}, 3 \mathrm{H}) 3.22(\mathrm{~m}, 2 \mathrm{H}) 4.18-4.25(\mathrm{~m}, 2 \mathrm{H})$ $3.57-3.62(\mathrm{~m}, 1 \mathrm{H}) 6.55(\mathrm{~d}, \mathrm{~J}=3.36 \mathrm{~Hz}, 1 \mathrm{H}) 6.68-$ $6.77(\mathrm{~m}, 2 \mathrm{H}) 6.65-7.12(\mathrm{~m}, 1 \mathrm{H}) 6.63(\mathrm{~s}, 1 \mathrm{H})$;

3-(3-bromo-4-oxy-5-methoxy)-2-(furan-2-yl-, 5-bromofuran-2-yl)-1,2,4-triazol-5-yl) thio) prop2-en-1-ole (compound 19): NMR ${ }^{1} \mathrm{H}(400 \mathrm{MHz}$, DMSO-d6) $\delta$ ppm $3.76(\mathrm{~s}, 3 \mathrm{H}) 4.18-4.25(\mathrm{~m}, 2 \mathrm{H})$ $3.57-3.62(\mathrm{~m}, 1 \mathrm{H}) 6.55(\mathrm{~d}, \mathrm{~J}=3.36 \mathrm{~Hz}, 1 \mathrm{H}) 6.68-$ $6.77(\mathrm{~m}, 2 \mathrm{H}) 6.65-7.12(\mathrm{~m}, 1 \mathrm{H}) 6.63(\mathrm{~s}, 1 \mathrm{H})$;

3 - (4-hydroxyphenyl)-2-(furan-2-yl-, 5-bromofuran-2-yl)-1,2,4-triazol-5-yl) thio) prop2-en-1-ole (compound 20): NMR ${ }^{1} \mathrm{H}(400 \mathrm{MHz}$, DMSO-d6) $\delta$ ppm 5,37 (s, $1 \mathrm{H}) 4.15-4.22(\mathrm{~m}, 2 \mathrm{H})$ $3.55-3.65(\mathrm{~m}, 1 \mathrm{H}) 6.61(\mathrm{~d}, \mathrm{~J}=3.36 \mathrm{~Hz}, 1 \mathrm{H}) 6.54-$ $6.64(\mathrm{~m}, 4 \mathrm{H}) 6.33-6.77(\mathrm{~m}, 1 \mathrm{H}) 6.35(\mathrm{~s}, 1 \mathrm{H})$;

3-(3,4-dimethoxyphenyl)-2-(furan-2-yl-, 5-bromofuran-2-yl)-1,2,4-triazol-5-yl) thio) prop2-en-1-ole (compound 21): NMR ${ }^{1} \mathrm{H}(400 \mathrm{MHz}$, DMSO-d6) $\delta$ ppm $1.76(\mathrm{~s}, 6 \mathrm{H}) 3.66-3.77(\mathrm{~m}, 2 \mathrm{H})$ 4.27-4.32 (m, $1 \mathrm{H}) 6.59(\mathrm{~d}, \mathrm{~J}=3.36 \mathrm{~Hz}, 1 \mathrm{H}) 6.65-$ $6.71(\mathrm{~m}, 3 \mathrm{H}) 6.78-6.82(\mathrm{~m}, 1 \mathrm{H}) 8.29(\mathrm{~s}, 1 \mathrm{H})$;

3-(3,5-dimethoxyphenyl)-2-(furan-2-yl-, 5-bromofuran-2-yl)-1,2,4-triazol-5-yl) thio) prop2-en-1-ole (compound 22): NMR ${ }^{1} \mathrm{H}(400 \mathrm{MHz}$, DMSO-d6) $\delta$ ppm $1.65(\mathrm{~s}, 6 \mathrm{H}) 3.62-3.73(\mathrm{~m}, 2 \mathrm{H})$ $4.23(\mathrm{t}, \mathrm{J}=6.30 \mathrm{~Hz}, 1 \mathrm{H}) 6.28-6.43(\mathrm{~m}, 4 \mathrm{H}) 6.51-$ $6.54(\mathrm{~m}, 1 \mathrm{H}) 6.71(\mathrm{~s}, 1 \mathrm{H})$.

The antibacterial activity of synthesized compounds on cryogenic strains of Enterococus faecalis, Proteus mirabilis, Proteus vulgaris, Serratia marcense, Salmonella adobraco, Salmonella typhimurium, Staphylococcus epidermidis, Bacillus subtilis, Listeria ivanovi, Listeria innocua, Listeria monocytogenes, Campylobacter jejuni, Rhodococcus equi and Candida albicans has been also investigated.

According to the obtained data, one can conclude that the investigated compounds can compete with kanamycin, a natural broad-spectrum antibiotic from the second generation of aminoglycosides, the action spectrum of which includes gram-positive and gram-negative microorganisms $[13,14]$. Thus, the compounds involved may be recommended for further investigations concerning multi-resistant strains of microorganisms.

\section{Conclusions}

A number of new compounds, 5- $\mathrm{R}_{2}-2$ - (furan2-yl-, 5- bromofuran-2-yl) thiazolo $[3,2-b][1,2,4]$ triazole-4 $(5 H)$-ones, have been synthesized with a high yield for the first time. Their reduction by an excess of sodium borohydride was investigated. The reduction was performed in a methanol medium in the presence of a triple quantity of sodium borohydride passes with the formation of corresponding 3- $\mathrm{R}_{2}-2-((3-$ (furan-2-yl, 5-bromofuran-2-yl)-1,2,4-triazol-5-yl) thio)-prop-2-en-1oles.

The structure of the synthesized compounds was confirmed by NMR ${ }^{1} \mathrm{H}$ spectroscopy, X-ray microanalysis and chromatography. The synthesized compounds can be used as antibacterial agents, they may successfully compete with kanamycin.

\section{REFERENCES}

1. Design, synthesis and biological evaluation of Schiff bases of 4-amino-1,2,4-triazole derivatives as potent angiotensin converting enzyme inhibitors and antioxidant activities / Saadaoui I., Krichen F., Ben Salah B., Ben Mansour R., Miled N., Bougatef A., Kossentini M. // J. Mol. Struct. - 2019. - Vol.1180. - P.344-354.

2. Bansode S. Synthesis of novel 2-(3'-aryl-sydnon-4'ylidene)-5'-substituted-[1,3,4]-thiadiazolylamines and [1,3,4]thiadiazol-2'-yl-3-oxo-[1,2,4]-triazoles as antimicrobial agents / S. Bansode, R. Kamble // Med. Chem. Res. - 2012. - Vol.21. P.867-873.

3. Synthesis and antimicrobial activity evaluation of some substituted N'[arylidene]-2-(3-methyl-5-pyridin-4-yl-1H-1,2,4triazol-1-yl) acetohydrazide compounds / S.G. Khanage, P.B. Mohite, R.B. Pandhare, A.S. Raju // Biointerface Res. Appl. Chem. - 2012. - Vol.2. - No. 5. - P.417-423.

4. Alrawashdeh M.S.M. Determination of antimicrobial activity of some 1,2,4-triazole derivatives // Reg. Mech. Biosyst. - 2018. - Vol.9. - No. 2. - P.203-208.

5. Studying of 2-((5-R-4-R1-4H-1,2,4-triazole-3il)thio)acetic acid salts influence on growth and progress of blackberries (KIOWA variety) propagules / Shcherbyna R.O., Danilchenko D.M., Parchenko V.V., Panasenko O.I., Knysh E.H., Hromyh N.A., Lyholat Y.V. // Res. J. Pharm. Biol. Chem. Sci. - 2017. - Vol.8. - No. 3. - P.975-979.

6. Kumar P., Kumar A., Makrandi J.K. Synthesis and evaluation of bioactivity of thiazolo[3,2-b]-[1,2,4]-triazoles and isomeric thiazolo[2,3-c]-[1,2,4]-triazoles // J. Heterocycl. Chem. - 2013. - Vol.50. - P.1223-1229.

7. Boyko O.O., Zazharska N.M., Brygadyrenko V.V. The influence of the extent of infestation by helminths upon changes in body weight of sheep in Ukraine // Visn. Dnipropetr. Univ. Biol. Ekol. - 2016. - Vol.24. - No. 1. - P.3-7.

8. Zazharska N., Boyko O., Brygadyrenko V. Influence of diet on the productivity and characteristics of goat milk // Indian J. Anim. Res. - 2018. - Vol.52. - No. 5. - P.711-717.

9. Bactericidal, protistocidal and nematodicidal properties of mixtures of alkyldimethylbenzyl ammonium chloride, didecyldimethyl ammonium chloride, glutaraldehyde and formaldehyde / Zazharskyi V.V., Davydenko P., Kulishenko O., 
Chumak V., Kryvaya A., Biben I.A., Tishkina N.M., Borovik I., Boyko O.O., Brygadyrenko V.V. // Regul. Mech. Biosyst. - 2018. - Vol.9. - No. 4. - P.540-545.

10. Bihdan O.A., Parchenko V.V. Some aspects of synthesis 3-(2-florphenyl)-6-R1-[1,2,4]triazol[3,4-b][1,3,4]thiadiazole and 3-(2-, 3-ftorphenyl)-6-R2-7H[1,2,4]triazolo[1,3,4]tiadiazines // Res. J. Pharm. Biol. Chem. Sci. - 2018. - Vol.9. - No. 3. P.463-470.

11. Antibacterial activities of ethanol extracts of Philippine medicinal plants against multidrug-resistant bacteria / Valle D.L., Andrade J.I., Puzon J.J.M., Cabrera E.C., Rivera W.L. // Asian Pac. J. Trop. Biomed. - 2015. - Vol.5. - No. 7. - P.532-540.

12. Studying of physico-chemical properties of 5-(2-,3fluorophenyl)-4-((aryl-, geteryl) yliden) amino-1,2,4-triazole-3thiols and any of their retrievalproducts / Bihdan O., Parchenko V., Zazharskyi V., Fotina T., Davydenko P. // Res. J. Pharm. Biol. Chem. Sci. - 2019. - Vol.10. - No. 1. - P.464-474.

13. Influence of 3-(3-fluorophenyl)-6-(4-methoxyphenyl)$7 \mathrm{H}$-[1,2,4]-triazolo-[3,4-b][1,3,4]thiadiazine on the cultural properties of pathogenic Mycobacterium bovis / Bihdan O., Parchenko V., Zazharskyi V., Fotina T., Davydenko P. // Res. J. Pharm. Biol. Chem. Sci. - 2019. - Vol.9. - No. 6. - P.166-170.

14. Rodriguez-Cavallini E., Vargas-Dengo P. Etiologyia bacteriana y susceptiblidad a antibioticos en pacientes con acne / / Rev. Biomed. - 2004. - Vol.15. - P.101-106.

Received 12.04.2019

\section{СИНТЕЗ, СТРУКТУРА, ФІЗИКО-ХІМІЧНІ ВЛАСТИВОСТІ ТА АНТИБАКТЕРІАЛЬНА АКТИВНІСТЬ ПОХІДНИХ 1,2,4-ТРИАЗОЛ-3-ТІОЛІВ І ФУРАНУ}

В. Зажсарський, М. Парченко, Т. Фотіна, П. Давиденко, О. Кулішенко, Н. Зажсарська, І. Боровик

Нові сполуки, фрагменти молекул яких є залишками 1,2,4-триазол-3-тіолів $і$ фуранів, а саме низку нових 5- $R_{2}-2$ (фуран-2-іл-, 5-бромофуран-2-іл) тіазоло [3,2-b] [1,2,4] mpuазол-4 (5H) -онів був уперше синтезований із високими виходами. Досліджено реакцію їх відновлення надлишком натрію борогідриду. Структуру сполук підтверджено методами ${ }^{1}$ Н ЯМР спектроскопії, рентгенівського мікроаналізу і хроматографії. Відновлення 5-R2-2- (фуран-2-іл, 5-бромофуран-2-іл) тіазоло [3,2-b] [1,2,4] триазол-4 (5H) -онів в метанольному середовищі за наявності потрійної кількості натрію борогідриду відбувається із утворенням відповідного 3- $R_{2}-2-((3-$ (фуран-2-iл, 5-бромофуран-2-іл)-1,2,4-триазол-5-іл) тіо)-проп-2-ен-1-олу. Було досліджено антибактеріальну активність синтезованих сполук відносно до кріогенних штамів Enterococus faecalis, Proteus mirabilis, Proteus vulgaris, Serratia marcense, Salmonella adobraco, Salmonella typhimurium, Staphylococcus epidermidis, Bacillus subtilis, Listeria ivanovi, Listeria innocua, Listeria monocytogenes, Campylobacter jejuni, Rhodococcus equi ma Candida albicans. Отримані дані свідчать про те, що досліджувані сполуки можуть конкурувати з канаміцином, природним антибіотиком широкого спектра дії з аміноглікозидів другого покоління, спектр дії якого включає грампозитивні і грамнегативні мікроорганізми. Використовувані сполуки можуть бути рекомендовані для подальших досліджень щодо мультирезистентних штамів мікроорганізмів.
Ключові слова: циклізація, 1,2,4-триазол, відновлення, фізико-хімічні властивості, антибактеріальна активність.

\section{SYNTHESIS, STRUCTURE, PHYSICOCHEMICAL PROPERTIES AND ANTIBACTERIAL ACTIVITY OF 1,2,4-TRIAZOLES-3-THIOLS AND FURAN DERIVATIVES}

V. Zazharskyi ${ }^{a,}$, M. Parchenko ${ }^{b}$, T. Fotina ${ }^{c}$, P. Davydenko ${ }^{a}$, O. Kulishenko ${ }^{a}$, N. Zazharskaya ${ }^{a}$, I. Borovik ${ }^{d}$

${ }^{a}$ Dnipro State Agrarian and Economic University, Dnipro, Ukraine

b Zaporizhzhia State Medical University, Zaporizhzhia, Ukraine c Sumy National Agrarian University, Sumy, Ukraine

d Dnipro Region State Laboratory of Veterinary Medicine, Dnipro, Ukraine

* e-mail: zazharskiyv@gmail.com

New compounds, 5- $R_{2}-2$ - (furan-2-yl-,5-bromofuran-2-yl) thiazolo [3,2-b][1,2,4] triazole-4 (5H)-ones, have been synthesized with a high yield for the first time. Molecules of these compounds contain the residuals of 1,2,4-triazole-3-thiols and furan. The reaction of their reduction by an excess of sodium borohydride was investigated. The structure of the synthesized compounds was confirmed by NMR ${ }^{1} H$ spectroscopy, X-ray microanalysis and chromatography. The reduction of 5- $R_{2}-2$-(furan-2-yl-,5-bromofuran-2-yl) thiazolo $[3,2-b][1,2,4]$ triazole-4 (5H)-ones in a methanol medium in the presence of a triple quantity of sodium borohydride occurs with the formation of corresponding 3- $R_{2}-2-((3-(f u r a n-2-y l, 5$-bromofuran2-yl)-1,2,4-triazol-5-yl) thio)-prop-2-en-1-oles. The antibacterial activity of the synthesized compounds towards the cryogenic strains of Enterococus faecalis, Proteus mirabilis, Proteus vulgaris, Serratia marcense, Salmonella adobraco, Salmonella typhimurium, Staphylococcus epidermidis, Bacillus subtilis, Listeria ivanovi, Listeria innocua, Listeria monocytogenes, Campylobacter jejuni, Rhodococcus equi and Candida albicans was investigated. According to the obtained data, the investigated compounds can compete with kanamycin, a natural broad-spectrum antibiotic from the second generation of aminoglycosides, the action spectrum of which includes gram-positive and gram-negative microorganisms. The compounds involved may be recommended for further investigations concerning multi-resistant strains of microorganisms.

Keywords: cyclization; 1,2,4-triazole; reduction; physicochemical properties; antibacterial activity.

\section{REFERENCES}

1. Saadaoui I., Krichen F., Ben Salah B., Ben Mansour R., Miled N., Bougatef A., Kossentini M. Design, synthesis and biological evaluation of Schiff bases of 4-amino-1,2,4-triazole derivatives as potent angiotensin converting enzyme inhibitors and antioxidant activities. Journal of Molecular Structure, 2019, vol. 1180 , pp. 344-354.

2. Bansode S., Kamble R. Synthesis of novel 2-(3'-arylsydnon-4'-ylidene)-5'-substituted-[1,3,4]-thiadiazolylamines and $[1,3,4]$-thiadiazol-2'-yl-3-oxo-[1,2,4]-triazoles as antimicrobial agents. Medicinal Chemistry Research, 2012, vol. 21, pp. 867-873.

3. Khanage S.G., Mohite P.B., Pandhare R.B., Raju A.S. Synthesis and antimicrobial activity evaluation of some substituted N'[arylidene]-2-(3-methyl-5-pyridin-4-yl-1H-1,2,4-triazol-1-yl) acetohydrazide compounds. Biointerface Research in Applied Chemistry, 2012, vol. 2. No. 5, pp. 417-423. 
4. Alrawashdeh M.S.M. Determination of antimicrobial activity of some 1,2,4-triazole derivatives. Regulatory Mechanisms in Biosystems, 2018, vol. 9, no. 2, pp. 203-208.

5. Shcherbyna R.O., Danilchenko D.M., Parchenko V.V., Panasenko O.I., Knysh E.H., Hromyh N.A., Lyholat Y.V. Studying of 2-((5-R-4-R1-4H-1,2,4-Triazole-3-il)thio)acetic acid salts influence on growth and progress of blackberries (KIOWA variety) propagules. Research Journal of Pharmaceutical, Biological and Chemical Sciences, 2017, vol. 8, no. 3, pp. 975-979.

6. Kumar P., Kumar A., Makrandi J.K. Synthesis and evaluation of bioactivity of thiazolo[3,2-b]-[1,2,4]-triazoles and isomeric thiazolo[2,3-c]-[1,2,4]-triazoles. Journal of Heterocyclic Chemistry, 2013, vol. 50, pp. 1223-1229.

7. Boyko O.O., Zazharska N.M., Brygadyrenko V.V. The influence of the extent of infestation by helminths upon changes in body weight of sheep in Ukraine. Visnyk Dnipropetrovs'kogo Universytetu. Biologiya. Ekologiya, 2016, vol. 24, no. 1, pp. 3-7.

8. Zazharska N., Boyko O., Brygadyrenko V. Influence of diet on the productivity and characteristics of goat milk. Indian Journal of Animal Research, 2018, vol. 52, no. 5, pp. 711-717.

9. Zazharskyi V.V., Davydenko P., Kulishenko O., Chumak V., Kryvaya A., Biben I.A., Tishkina N.M., Borovik I., Boyko O.O., Brygadyrenko V.V. Bactericidal, protistocidal and nematodicidal properties of mixtures of alkyldimethylbenzyl ammonium chloride, didecyldimethyl ammonium chloride, glutaraldehyde and formaldehyde. Regulatory Mechanisms in Biosystems, 2018, vol. 9, no. 4, pp. 540-545.
10. Bihdan O.A., Parchenko V.V. Some aspects of synthesis 3- (2-florphenyl) -6-r1- [1,2,4] triazol [3,4-b] [1,3,4] thiadiazoleand 3-(2-, 3-ftorphenyl)-6-r2-7h [1,2,4] triazolo [3,4-b] [1,3,4] tiadiazines. Research Journal of Pharmaceutical, Biological and Chemical Sciences, 2018, vol. 9, no. 3, pp. 463-470.

11. Valle D.L., Andrade J.I., Puzon J.J.M., Cabrera E.C., Rivera W.L. Antibacterial activities of ethanol extracts of Philippine medicinal plants against multidrug-resistant bacteria. Asian Pacific Journal of Tropical Biomedicine, 2015, vol. 5, pp. 532-540.

12. Bihdan O., Parchenko V., Zazharskyi V., Fotina T., Davydenko P. Studying of physico-chemical properties of 5-(2-,3-fluorophenyl)-4-((aryl-, geteryl) yliden) amino-1,2,4triazole-3-thiols and any of their retrievalproducts. Research Journal of Pharmaceutical, Biological and Chemical Sciences, 2019, vol. 10 , no. 1 , pp. 464-474.

13. Bihdan O., Parchenko V., Zazharskyi V., Fotina T., Davydenko P. Influence of 3-(3-fluorophenyl)-6-(4methoxyphenyl)-7H-[1,2,4]-triazolo-[3,4-b][1,3,4]thiadiazine on the cultural properties of pathogenic Mycobacterium bovis. Research Journal of Pharmaceutical, Biological and Chemical Sciences, 2019, vol. 9, no. 6, pp. 166-170.

14. Rodriguez-Cavallini E., Vargas-Dengo P. Etiologyia bacteriana y susceptiblidad a antibioticos en pacientes con acne. Revista Biomedica, 2004, vol. 15, pp. 101-106. (in Spanish). 